\title{
Regulation of flagellar motility of fowl spermatozoa: evidence for the involvement of intracellular free $\mathrm{Ca}^{2+}$ and calmodulin
}

\author{
K. Ashizawa, H. Tomonaga and Y. Tsuzuki \\ Laboratory of Animal Reproduction, Faculty of Agriculture, Miyazaki University, \\ Miyazaki 889-21, Japan
}

\begin{abstract}
The possible role of intracellular free $\mathrm{Ca}^{2+}$ and calmodulin in the regulation of fowl sperm motility was investigated using an intracellular $\mathrm{Ca}^{2+}$ chelator, 1,2-bis (2-aminophenoxy) ethane- $N, N, N^{\prime}, N^{\prime}$-tetraacetic acid, tetraacetoxymethyl ester (BAPTA/AM) and calmodulin antagonists such as $\mathrm{N}$-(6-aminohexyl)-5-chloro-1-naphthalenesulfonamide hydrochloride (W-7), N-(6-aminohexyl)-1-naphthalenesulfonamide hydrochloride (W-5) and trifluoperazine. Intact fowl spermatozoa maintained vigorous movement in a $\mathrm{Ca}^{2+}$-free medium at $30^{\circ} \mathrm{C}$. In contrast, the motility of spermatozoa loaded with BAPTA/AM was negligible at $30^{\circ} \mathrm{C}$, but could be instantly restored by the addition of $2 \mathrm{mmol} \mathrm{CaCl}, \mathrm{l}^{-1}$. At this time, the intracellular free $\mathrm{Ca}^{2+}$ concentrations increased from 0 to about $100 \mathrm{nmol} \mathrm{l}^{-1}$, as measured by the fluorescent $\mathrm{Ca}^{2+}$ indicator fura-2. At $40^{\circ} \mathrm{C}$, neither control nor BAPTAJAM-treated spermatozoa were motile, but the motility of both kinds of spermatozoa was restored by the subsequent addition of $2 \mathrm{mmol} \mathrm{CaCl} \mathrm{l}^{-1}$. Even in the presence of $2 \mathrm{mmol} \mathrm{CaCl} \mathrm{l}^{-1}$, the addition of W-7 and trifluoperazine inhibited the motility of intact spermatozoa at $30^{\circ} \mathrm{C}$ and $40^{\circ} \mathrm{C}$, and induced a concomitant decrease in the rate of oxygen consumption and ATP concentration, suggesting that energy depletion might be involved in the inhibition of motility. In contrast, the motility of demembranated spermatozoa was not inhibited by the addition of W-7 and trifluoperazine at $30^{\circ} \mathrm{C}$. The addition of W-5, a weaker antagonist, did not appreciably affect the motility of either intact or demembranated spermatozoa. These results suggest that intracellular free $\mathrm{Ca}^{2+}$ is indispensable for the maintenance of fowl sperm motility. Calmodulin, which occurs in the cytoplasm or mitochondria but not in the axoneme, is a prominent candidate for the signal transducer in $\mathrm{Ca}^{2+}$-stimulated motility.
\end{abstract}

\section{Introduction}

It is well known that $\mathrm{Ca}^{2+}$ is a signal transducer in the regulation of sperm motility (for review, see Tash and Means, 1983; Lindemann and Kanous, 1989; Majumder et al., 1990). The effects of intracellular $\mathrm{Ca}^{2+}$ on sperm motility can be divided into two major classes: modification of wave form and oscillation frequency (Gibbons and Gibbons, 1973; Brokaw et al., 1974; Brokaw, 1979; Lindemann et al., 1987; Suarez et al., 1993); and complete inhibition of motility at $>1 \mu \mathrm{mol} \mathrm{Ca}^{2+} 1^{-1}$ (Gibbons and Gibbons, 1980; Mohri and Yanagimachi, 1980; Tash and Means, 1982).

Since the inhibition of mammalian sperm motility by high concentrations of intracellular $\mathrm{Ca}^{2+}$ is paralleled by a decrease in the overall phosphorylation of sperm proteins, some of which may be axonemal components (Tash and Means, 1982), it is logical to presume that the effects of $\mathrm{Ca}^{2+}$ on sperm motility may be partly regulated by protein phosphorylation. The inhibitory effect of $\mathrm{Ca}^{2+}$ on protein phosphorylation could be explained by a direct effect of $\mathrm{Ca}^{2+}$ on protein

Received 24 August 1993 kinase activity, $\mathrm{Ca}^{2+}$-stimulated phosphoprotein phosphatase activity, or conformational changes within the axoneme that prevent enzyme-substrate interactions (Tash and Means, 1983).

However, fowl spermatozoa display a unique phenomenon: their motility is reversibly inhibited as the temperature is raised from $30^{\circ} \mathrm{C}$ to $40^{\circ} \mathrm{C}$, the avian body temperature (Munro, 1938; Nevo and Schindler, 1968; Ashizawa and Nishiyama, 1978: Takeda, 1982; Ashizawa and Okauchi, 1984; Ashizawa and Wishart, 1987; Wishart and Ashizawa, 1987; Ashizawa et al., 1989a). One of the possible mechanisms of this phenomenon involves a loss of intracellular $\mathrm{Ca}^{2+}$ to the suspending medium at $40^{\circ} \mathrm{C}$, with a subsequent resequestration of $\mathrm{Ca}^{2+}$ at a lower temperature (Thomson and Wishart, 1989, 1991). Motility is restored by decreasing the temperature or by the addition of $\mathrm{Ca}^{2+}$ at $40^{\circ} \mathrm{C}$ (Wishart and Ashizawa, 1987: Ashizawa et al., 1989a; Thomson and Wishart, 1989, 1991). In addition, the motility of demembranated fowl spermatozoa is also inhibited in $\mathrm{Ca}^{2+}$-free medium (Ashizawa et al., 1992a) and reactivation was observed with the addition of $10^{-3} \mathrm{~mol} \mathrm{Ca}{ }^{2+} \mathrm{l}^{-1}$ (Ashizawa et al., 1989b). In such a high concentration of $\mathrm{Ca}^{2+}$, the motility of demembranated ram and hamster spermatozoa 
was inhibited (White and Voglmayr, 1986; Feng et al., 1988). It therefore seems likely that there is a species difference in sensitivity to $\mathrm{Ca}^{2+}$, and $\mathrm{Ca}^{2+}$ is indispensable for the movement of fowl spermatozoa.

Calmodulin, the $\mathrm{Ca}^{2+}$-binding protein that modulates the activity of a number of key regulatory enzymes (Means $e t$ al., 1982), has been identified in spermatozoa from a diverse range of species, from sea urchins to humans (Brooks and Siegel, 1973; Jones et al., 1978, 1980; Garbers et al., 1980; Burgess, 1983; Moore and Dedman, 1984; Yamamoto, 1985; Camatini et al., 1986, 1991; Weinman et al., 1986; Fouquet et al., 1991; Kann et al., 1991). It has been suggested that calmodulin regulates flagellar motility in dog and sea urchin spermatozoa by inducing wave-form changes (Tash and Means, 1982; Brokaw and Nagayama, 1985) or by inhibition in human spermatozoa (Hong et al., 1985), as shown by anti-calmodulin drug treatment.

It may therefore be assumed that the $\mathrm{Ca}^{2+}$-sensitive motility of fowl spermatozoa described above is mostly regulated by the $\mathrm{Ca}^{2+}$-calmodulin complex rather than by $\mathrm{Ca}^{2+}$ directly. However, the presence of calmodulin or its role in the regulation of motility has not been demonstrated in fowl spermatozoa. In this study, attempts have been made to clarify the role of calmodulin in the regulation of flagellar motility and metabolic activity of fowl spermatozoa by using calmodulin antagonists. We have shown that fowl spermatozoa are rendered immotile at $30^{\circ} \mathrm{C}$ and $40^{\circ} \mathrm{C}$ by the addition of calmodulin antagonists, even in the presence of $\mathrm{Ca}^{2+}$.

\section{Materials and Methods}

\section{Animals and preparation of spermatozoa}

Commercial White Leghorn roosters (Babcock strain, Akagi Poultry Breeding Farm, Miyazaki) were used throughout the study. All birds were housed in individual cages and fed ad libitum on a commercial breeder diet. They were exposed to a photoperiod of $14 \mathrm{~h}$ light:10 h dark.

Semen was collected by the method of Bogdonoff and Shaffner (1954). Samples of semen pooled from four to six males were diluted by a factor of approximately 10 in $150 \mathrm{mmol} \mathrm{NaCl} \mathrm{I} \mathrm{I}^{-1}$ with $20 \mathrm{mmol}$ Tes (N-Tris[hydroxymethyl]-methyl-2-aminoethanesulphonic acid) $\mathrm{I}^{-1}$ at $\mathrm{pH} 7.4$ and centrifuged at $700 \mathrm{~g}$ for $13 \mathrm{~min}$ at room temperature $\left(20-25^{\circ} \mathrm{C}\right)$. The washed spermatozoa were reconstituted in the same buffer to give a final concentration of approximately $1 \times 10^{9}$ cells ml ${ }^{-1}$. Samples of $3-4 \mathrm{ml}$ were poured into $30 \mathrm{ml}$ Erlenmeyer flasks with screw caps.

\section{Chemicals}

1-(2-(5"-Carboxyoxazol-2"-yl)-6-aminobenzofuran-5-oxy)-2( $2^{\prime}$-amino-5'-methylphenoxy)-ethane- $N, N, N^{\prime}, N^{\prime}$-tetraacetic acid pentaacetoxymethyl ester (fura-2/AM) and 1,2-bis (2aminophenoxy) ethane- $N, N, N^{\prime}, N^{\prime}$-tetraacetic acid, tetraacetoxymethyl ester (BAPTA/AM) were purchased from Dojindo Laboratories, Inc, Kumamoto. $N$-(6-Aminohexyl)-5chloro-1-naphthalenesulfonamide hydrochloride (W-7) and $\mathrm{N}$-(6-aminohexyl)-1-naphthalenesulfonamide hydrochloride
(W-5) were obtained from Seikagaku Kogyo Co, Ltd, Tokyo. Trifluoperazine, ATP, dithiothreitol, potassium glutamate, Tes, Triton X-100, Cremophor EL and desiccated firefly tails were purchased from Sigma Chemical Co, St Louis, MO. Other chemicals were of reagent grade from Nacalai Tesque, Inc, Kyoto.

\section{Loading of spermatozoa with BAPTA/AM}

Stock solutions of BAPTA/AM were made up to $50 \mathrm{mmol}$ $1^{-1}$ in dry dimethylsulfoxide (DMSO) and kept desiccated at $4^{\circ} \mathrm{C}$ in the dark until use. For the complete emulsification of BAPTAJAM, $1 \mu \mathrm{l} 10 \%$ Cremophor EL was added to $2 \mu \mathrm{l}$ BAPTAVAM, and $1 \mathrm{ml}$ of Tes/ $\mathrm{NaCl}$ buffer was then added. This solution was sonicated for $2 \mathrm{~min}$ on ice using an ultrasonic processor with a microtip (Sonics and Materials, Inc, Danbury, $\mathrm{CT}$ ) at $50 \mathrm{~W}$. This procedure subsequently gave optimal conditions for BAPTA/AM cellular loading and hydrolysis. Sperm suspension $(0.1 \mathrm{ml})$ was added to $1 \mathrm{ml}$ BAPTA/AM solution and shaken for $90 \mathrm{~min}$ at room temperature $\left(20-25^{\circ} \mathrm{C}\right)$ in the dark. During this incubation, final concentrations of BAPTAJAM and spermatozoa were about $90 \mu \mathrm{mol} \mathrm{l}^{-1}$ and $0.9 \times 10^{8} \mathrm{ml}^{-1}$, respectively. Sperm preparations diluted with $\mathrm{Tes} / \mathrm{NaCl}$ buffer to the same concentrations described above and shaken for $90 \mathrm{~min}$ at room temperature were used as controls.

\section{Measurement of motility of intact and demembranated spermatozoa}

In the first series of experiments, the sperm preparations with or without BAPTA/AM treatment were incubated aerobically in a shaking water bath at $30^{\circ} \mathrm{C}$ or $40^{\circ} \mathrm{C}$. Five minutes after the start of incubation, $2 \mathrm{mmol} \mathrm{CaCl} \mathrm{I}^{-1}$ was added. During incubation of spermatozoa, the suspension of spermatozoa was placed in a microscope chamber (Sekisui Chemical Co, Ltd, Tokyo; UR-157 type; $0.07 \mathrm{~mm}$ in depth) and the motility of spermatozoa was recorded by videomicroscopy (magnification of the black and white monitor was approximately $\times 600$ ) at $30^{\circ} \mathrm{C}$ or $40^{\circ} \mathrm{C}$ on a thermostatically controlled warm plate (Katz and Overstreet, 1981). Measurements were made on 200-300 spermatozoa, distributed uniformly among the three or more fields, to determine percentage motility.

In the second series of experiments, the effects of calmodulin antagonists on the motility of intact and demembranated spermatozoa were examined. The dose-response and timecourse of motility were measured at $30^{\circ} \mathrm{C}$ after addition of various concentrations of $\mathrm{W}-5, \mathrm{~W}-7$ and trifluoperazine. The effects of the addition of $\mathrm{CaCl}_{2}$ before the addition of calmodulin antagonists were also examined at $30^{\circ} \mathrm{C}$ and $40^{\circ} \mathrm{C}$ to be compared with those of calmodulin antagonists alone. Sperm preparations were diluted with $\mathrm{Tes} / \mathrm{NaCl}$ buffer as described above for the measurement of motility intact spermatozoa. Demembranation and reactivation of spermatozoa were performed at $30^{\circ} \mathrm{C}$ according to the method described by Ashizawa et al. (1989b). The extraction medium used consisted of $0.1 \%$ Triton $X-100,0.2 \mathrm{~mol}$ sucrose $\mathrm{l}^{-1}, 25 \mathrm{mmol}$ potassium glutamate $1^{-1}, 1 \mathrm{mmol} \mathrm{MgSO}_{4} 1^{-1}, 1 \mathrm{mmol}$ dithiothreitol $1^{-1}$ 
and $20 \mathrm{mmol}$ Tris- $\mathrm{HCl}$ buffer $\mathrm{l}^{-1}(\mathrm{pH} 7.9)$. The reactivation medium consisted of 0.5 mmol ATP $1^{-1}, 0.2$ mol sucrose $\mathrm{l}^{-1}$, $25 \mathrm{mmol}$ potassium glutamate $\mathrm{l}^{-1}, 1.5 \mathrm{mmol} \mathrm{MgSO}_{4} \mathrm{l}^{-1}$, $1 \mathrm{mmol}$ dithiothreitol $\mathrm{l}^{-1}$ and $20 \mathrm{mmol}$ Tris- $\mathrm{HCl}$ buffer $\mathrm{l}^{-1}$ (pH 7.9).

\section{Measurement of intracellular free $\mathrm{Ca}^{2+}$ concentrations of intact spermatozoa}

Determination of the intracellular free $\mathrm{Ca}^{2+}$ concentrations was carried out with the fluorescent indicator fura-2, essentially according to Grynkiewicz et al. (1985) but with some modifications (Ashizawa et al., 1992a). Fluorescence intensity was measured with a dual-wavelength spectrofluorimeter (Shimadzu, Model RF-5000, Kyoto) with the sample chamber maintained at $30^{\circ} \mathrm{C}$ or $40^{\circ} \mathrm{C}$ by a circulating water jacket, and the sperm suspension was mixed continuously with a magnetic stirring bar. For the measurement of intracellular free $\mathrm{Ca}^{2+}$ concentrations, the excitation wavelength was set to 340 and $380 \mathrm{~nm}$, respectively, and the emission wavelength was set to $500 \mathrm{~nm}$. The ratio of fluorescence intensities at $340: 380 \mathrm{~nm}$ was monitored continuously. Calculation of intracellular free $\mathrm{Ca}^{2+}$ was based upon the equation described by Grynkiewicz et al. (1985) where a dissociation constant $\left(K_{\mathrm{d}}\right)$ was $224 \mathrm{nmol} \mathrm{I}^{-1}$.

\section{Measurement of oxygen consumption and ATP concentrations of intact spermatozoa}

Oxygen consumption of spermatozoa was determined polarographically with a Clark electrode by the method of Kielley (1963), using a YSI model 53 biological oxygen monitor (Yellow Springs Instrument $\mathrm{Co}$, Inc, Yellow Springs, $\mathrm{OH})$. The rate of oxygen consumption was expressed in terms of $\mu \mathrm{O} \mathrm{O}_{2}$ consumed $10^{-8}$ spermatozoa $\mathrm{h}^{-1}$. Numbers of spermatozoa were estimated by the method of Wishart and Ross (1985), using a double-beam spectrophotometer (Shimadzu, Model UV-150-02).

ATP concentration in spermatozoa was assayed by firefly bioluminescence in a boiled extract (Wishart, 1982).

\section{Statistical analysis} test.

Statistical comparisons were performed using Student's $t$

\section{Results}

Effects of BAPTA/AM on the motility and intracellular free $\mathrm{Ca}^{2+}$ concentrations of intact fowl spermatozoa

Intact fowl spermatozoa that were not treated with BAPTA/AM (control) maintained vigorous movement at $30^{\circ} \mathrm{C}$ in the presence or absence of $\mathrm{CaCl}_{2}$ in the suspending medium. By contrast, the motility of spermatozoa loaded with BAPTA $\mathrm{AM}$, an intracellular $\mathrm{Ca}^{2+}$ chelator, was negligible at $30^{\circ} \mathrm{C}$ but was instantly restored by the addition of $2 \mathrm{mmol} \mathrm{CaCl}_{2} \mathrm{I}^{-1}$ (Fig. 1a). At $40^{\circ} \mathrm{C}$, neither control nor BAPTA/AM-treated

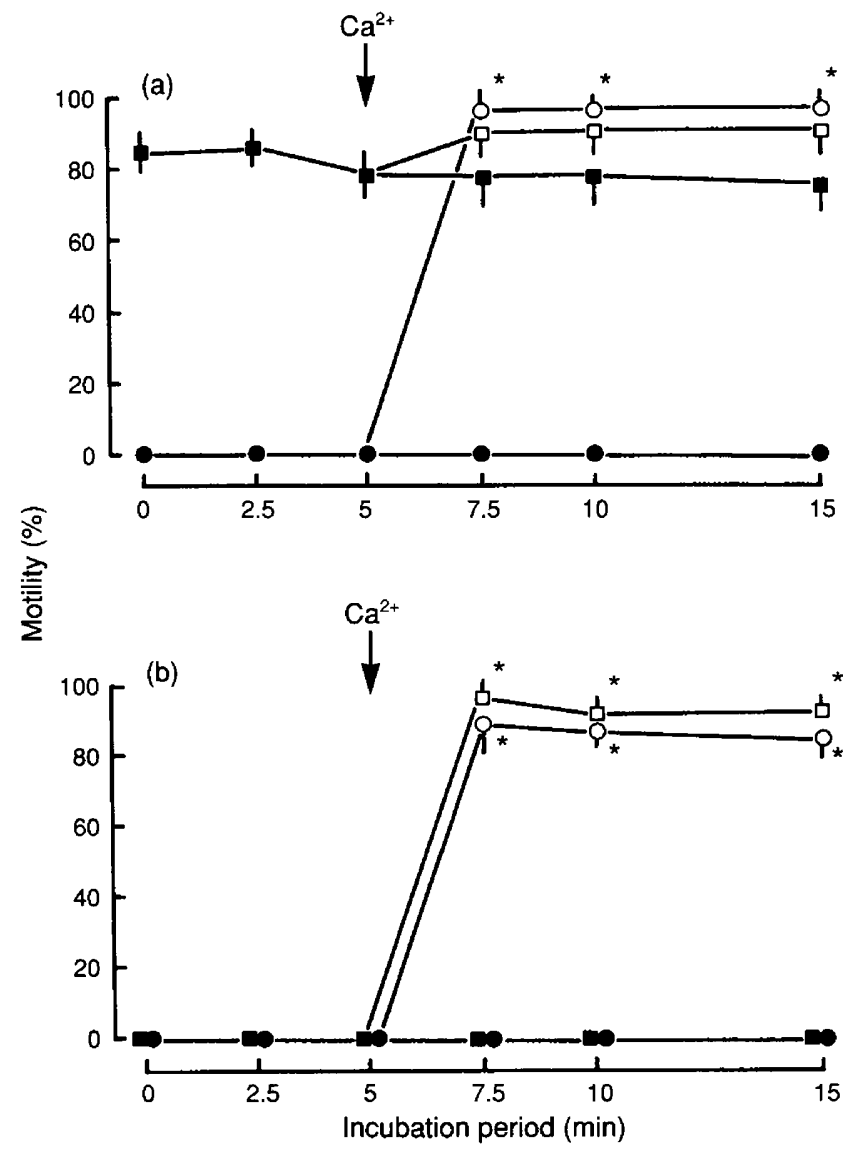

Fig. 1. The time-course of motility of intact fowl spermatozoa ( with or (a) without the intracellular $\mathrm{Ca}^{2+}$ chelator BAPTA/AM at (a)

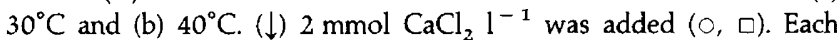
point represents the mean ( \pm SEM) of five samples of spermatozoa. ${ }^{*} P<0.01$, compared with value when $\mathrm{Ca}^{2+}$ was not added at each incubation period.

spermatozoa were motile, but the motility of both preparations was restored by the subsequent addition of $\mathrm{CaCl}_{2}$ (Fig. Ib).

The intracellular free $\mathrm{Ca}^{2+}$ concentration of intact spermatozoa before the addition of $\mathrm{CaCl}_{2}$ was approximately $20 \mathrm{nmol} 1^{-1}$ at $30^{\circ} \mathrm{C}$ and $40^{\circ} \mathrm{C}$. After the addition of $\mathrm{CaCl}_{2}$, the $\mathrm{Ca}^{2+}$ concentration increased rapidly and reached a plateau at approximately $200 \mathrm{nmol}^{-1}$. In contrast, the intracellular free $\mathrm{Ca}^{2+}$ concentration of BAPTA/AM-treated spermatozoa before the addition of $\mathrm{CaCl}_{2}$ was almost $0 \mathrm{nmol} 1^{-1}$ at $30^{\circ} \mathrm{C}$ and $40^{\circ} \mathrm{C}$. However, the addition of $2 \mathrm{mmol} \mathrm{CaCl} \mathrm{I}^{-1}$ caused an influx of $\mathrm{Ca}^{2+}$ from the medium and the $\mathrm{Ca}^{2+}$ concentration increased gradually at $30^{\circ} \mathrm{C}$. Similar results were obtained at $40^{\circ} \mathrm{C}$ (Fig. 2).

Effects of calmodulin antagonists on the motility of intact and demembranated fowl spermatozoa

The vigorous motility of intact spermatozoa at $30^{\circ} \mathrm{C}$ was inhibited in a dose-dependent manner by the addition of the calmodulin antagonists W-7 and trifluoperazine. In contrast, no inhibition of motility was observed following the addition of 


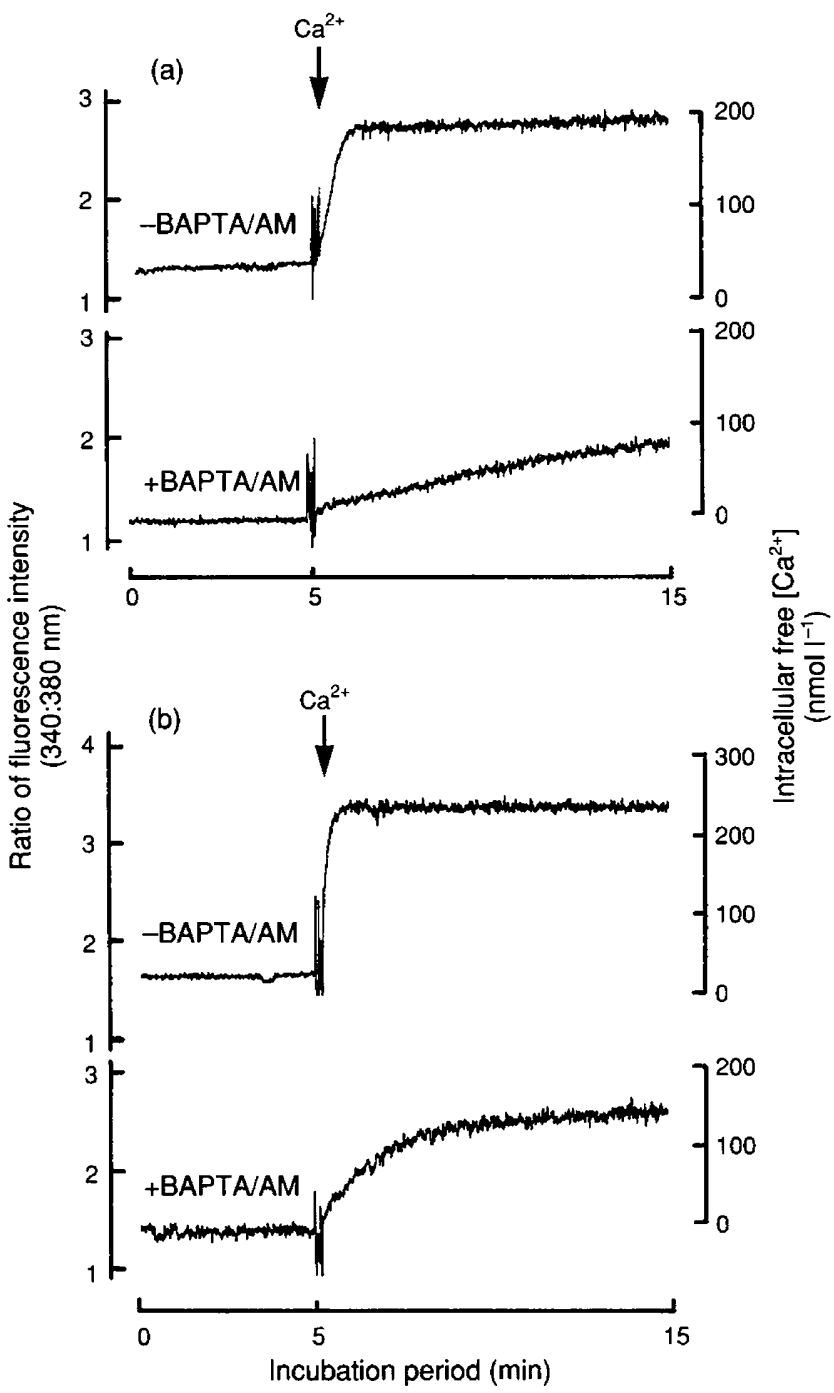

Fig. 2. Changes in the intracellular free $\mathrm{Ca}^{2+}$ concentration in fowl spermatozoa with or without the intracellular $\mathrm{Ca}^{2+}$ chelator BAPTA/AM at (a) $30^{\circ} \mathrm{C}$ and (b) $40^{\circ} \mathrm{C}$ measured by fura- 2 fluorescence. (1) $2 \mathrm{mmol} \mathrm{CaCl} \mathrm{l}^{-1}$ was added.

W-5, a weaker antagonist used as a control drug for W-7, at concentrations of $0-500 \mu \mathrm{mol} \mathrm{I}^{-1}$ (Fig. 3).

The inhibition of motility $20 \mathrm{~min}$ after the addition of these calmodulin antagonists is shown (Fig. 3). The time course of inhibition of motility by calmodulin antagonists at $30^{\circ} \mathrm{C}$ is shown (Fig. 4). Inhibition of motility by trifluoperazine was irreversible. However, inhibition was reversible in spermatozoa treated with W-7: the motility could be restored by diluting the spermatozoa samples by a factor of 20 in W-7-free assay medium to decrease the concentrations of $\mathrm{W}-7$ after exposure for $20 \mathrm{~min}$. However, inhibition of motility by the addition of W-7 and trifluoperazine was not observed in demembranated and reactivated spermatozoa at $30^{\circ} \mathrm{C}$ (Fig. 5), and motility was maintained for at least $30 \mathrm{~min}$ in these spermatozoa as well as in control and W-5-treated spermatozoa (Fig. 6).

Even the presence of $\mathrm{Ca}^{2+}$ before the addition of $\mathrm{W}-7$ and trifluoperazine could not prevent the inhibition of motility of intact spermatozoa at $30^{\circ} \mathrm{C}$ (Fig. $7 \mathrm{a}$ ). At $40^{\circ} \mathrm{C}$, the motility of

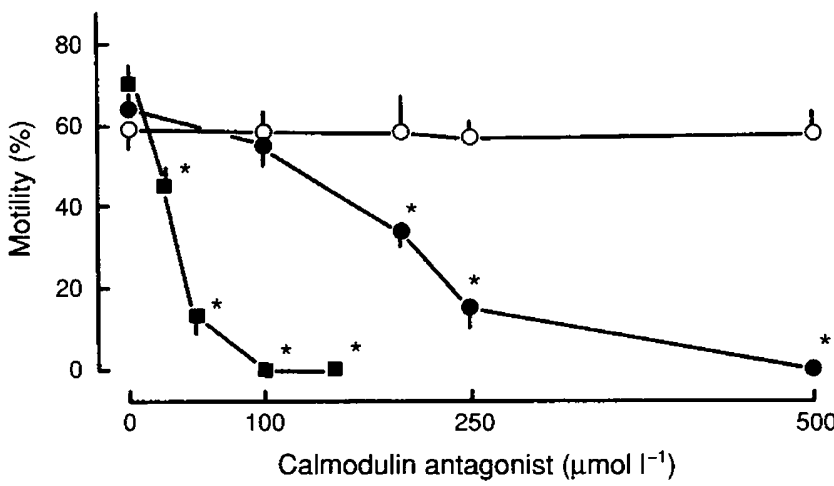

Fig. 3. Motility of intact fowl spermatozoa after addition of various concentrations of the calmodulin antagonists W-7 $(\bullet), W-5(0)$ and trifluoperazine ( $)$ at $30^{\circ} \mathrm{C}$. The motility of spermatozoa was assessed 20 min after the addition of calmodulin antagonists at each concentration. Each point represents the mean ( \pm SEM) of five samples of spermatozoa. ${ }^{*} P<0.01$ compared with value at $0 \mu \mathrm{mol} \mathrm{l}^{-1}$.

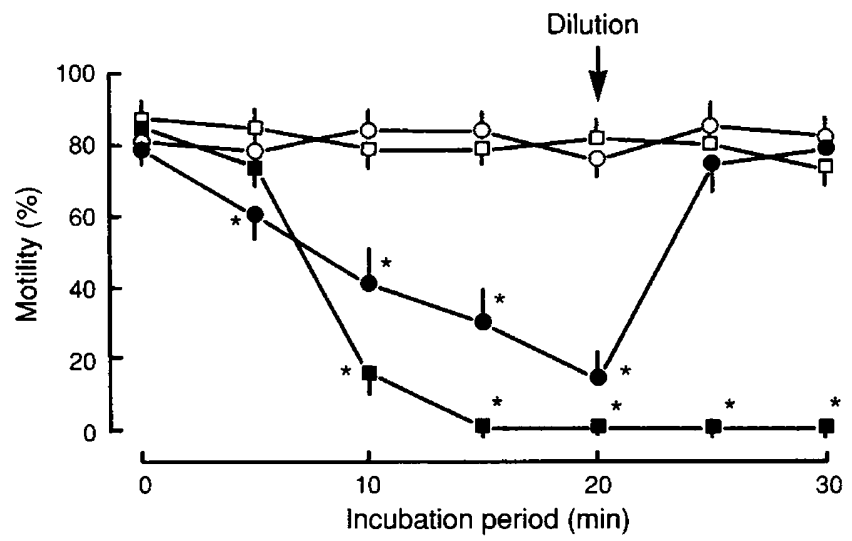

Fig. 4. The time-course of motility of intact fowl spermatozoa at

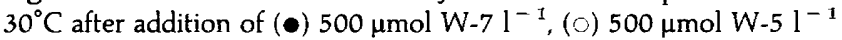
and (-) $100 \mu \mathrm{mol}$ trifluoperazine $\mathrm{l}^{-1}$; no addition of antagonist (control) ( $\square$ ). At arrow, sperm samples were diluted by a factor of 20 in antagonist-free assay medium to decrease extracellular antagonist concentrations. Each point represents the mean ( \pm SEM) of five samples of spermatozoa. ${ }^{*} P<0.01$ compared with value at $0 \mathrm{~min}$.

intact spermatozoa was negligible, but was restored immediately after the addition of $2 \mathrm{mmol} \mathrm{CaCl} \mathrm{I}^{-1}$. However, the subsequent addition of $\mathrm{W}-7$ and trifluoperazine inhibited the motility again (Fig. 7b). During this period, the intracellular free $\mathrm{Ca}^{2+}$ concentration maintained a constant value at approximately $200 \mathrm{nmol} \mathrm{l}^{-1}$ (data not shown). Furthermore, the motility of BAPTA/AM-treated spermatozoa could not be restored by the addition of both $\mathrm{W}-7$ and $\mathrm{CaCl}_{2}$ at $30^{\circ} \mathrm{C}$ and $40^{\circ} \mathrm{C}$, but was instantly restored by the addition of $\mathrm{CaCl}_{2}$ alone (Fig. $7 \mathrm{c}, \mathrm{d}$ ).

Effects of BAPTA/AM and calmodulin antagonists on the oxygen consumption and ATP concentrations of intact fowl spermatozoa

The oxygen consumption of spermatozoa that were treated with BAPTA $/ A M$ at $30^{\circ} \mathrm{C}$ and $40^{\circ} \mathrm{C}$ was $3.4 \pm 0.1$ and $4.2 \pm 0.3 \mathrm{MlO}_{2} \quad 10^{-8}$ spermatozoa $h^{-1}$ (mean \pm SEM of five 


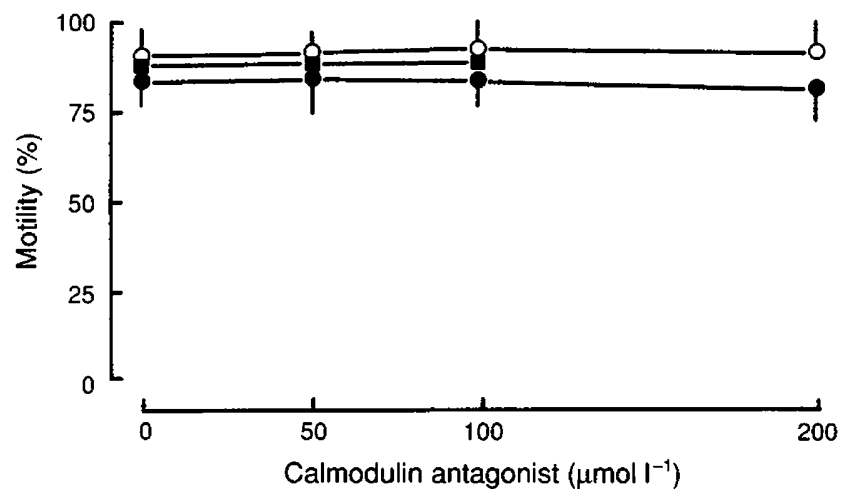

Fig. 5. Motility of demembranated fowl spermatozoa after addition of various concentrations of the calmodulin antagonists $(\bullet) W-7,(0)$ W-5 and (a) trifluoperazine at $30^{\circ} \mathrm{C}$. Spermatozoa were assayed for motility $20 \mathrm{~min}$ after the addition of calmodulin antagonists at each concentration. Each point represents the mean ( \pm SEM) of five samples of spermatozoa.

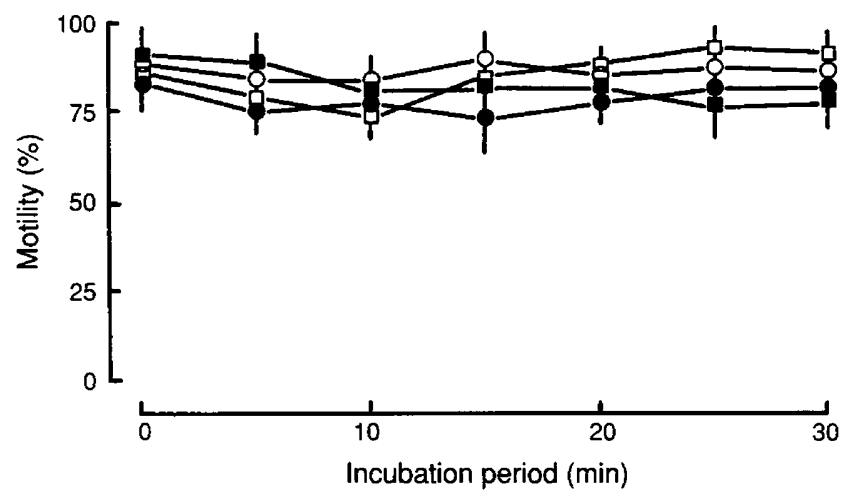

Fig. 6. The time-course of motility of demembranated fowl spermatozoa at $30^{\circ} \mathrm{C}$ after the addition of (•) $100 \mu \mathrm{mol} \mathrm{W}-7 \mathrm{l}^{-1},(0)$ $100 \mu \mathrm{mol} \mathrm{W}-5 \mathrm{l}^{-1}$ and (a) $50 \mu \mathrm{mol}$ trifluoperazine $\mathrm{I}^{-1}$; no addition of antagonist (control) ( $\square$ ). Each point represents the mean ( \pm SEM) of five samples of spermatozoa.

samples), respectively. At both temperatures, there were significant differences $(P<0.01)$ between these spermatozoa and those not treated with BAPTA $/ \mathrm{AM}$ (control) $\left(5.4 \pm 0.2\right.$ at $30^{\circ} \mathrm{C}$ and $6.2 \pm 0.4$ at $40^{\circ} \mathrm{C}$ ).

Furthermore, the rate of oxygen consumption of intact spermatozoa increased slightly after the addition of $2 \mathrm{mmol}$ $\mathrm{CaCl}_{2} 1^{-1}$ at $30^{\circ} \mathrm{C}$ and $40^{\circ} \mathrm{C}$, but decreased significantly

Fig. 7. Motility of intact fowl spermatozoa after addition $(\downarrow)$ of $(a)(0)$

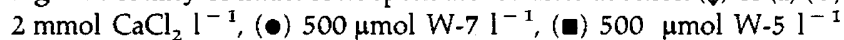
and (口) $100 \mu \mathrm{mol}$ trifluoperazine $1^{-1}$ at $30^{\circ} \mathrm{C}$, and (b) (O) $2 \mathrm{mmol}$

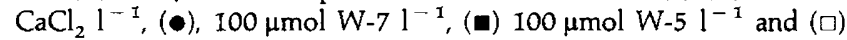
$50 \mu \mathrm{mol}$ trifluoperazine $1^{-1}$ at $40^{\circ} \mathrm{C}$. Motility of BAPTA/AM-treated intact fowl spermatozoa before $(\bullet)$ and after addition $(\downarrow)$ of $(c)(\square)$ $2 \mathrm{mmol} \mathrm{CaCl} \mathrm{I}^{-1}$ and (O) $2 \mathrm{mmol} \mathrm{CaCl} \mathrm{l}^{-1}+500 \mu \mathrm{mol} \mathrm{W}-7 \mathrm{l}^{-1}$ at $30^{\circ} \mathrm{C}$, and (d) () $2 \mathrm{mmol} \mathrm{CaCl}_{2} \mathrm{I}^{-1}$ and (O) $2 \mathrm{mmol} \mathrm{CaCl}_{2}$ $\mathrm{l}^{-1}+100 \mu \mathrm{mol} W-7 \mathrm{l}^{-1}$ at $40^{\circ} \mathrm{C}$. Each point represents the mean ( $\pm \mathrm{SEM}$ ) of five samples of spermatozoa. ${ }^{*} P<0.01$ compared with value when calmodulin antagonist was not added (control) at each period.
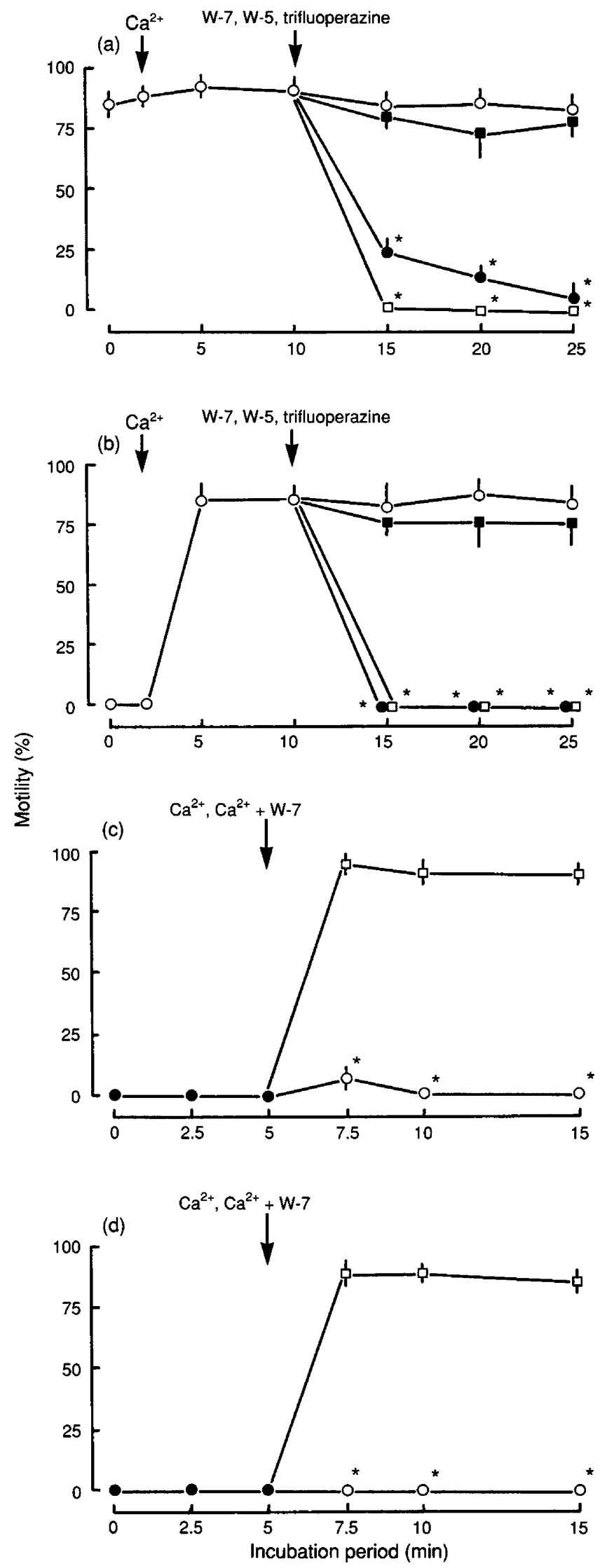

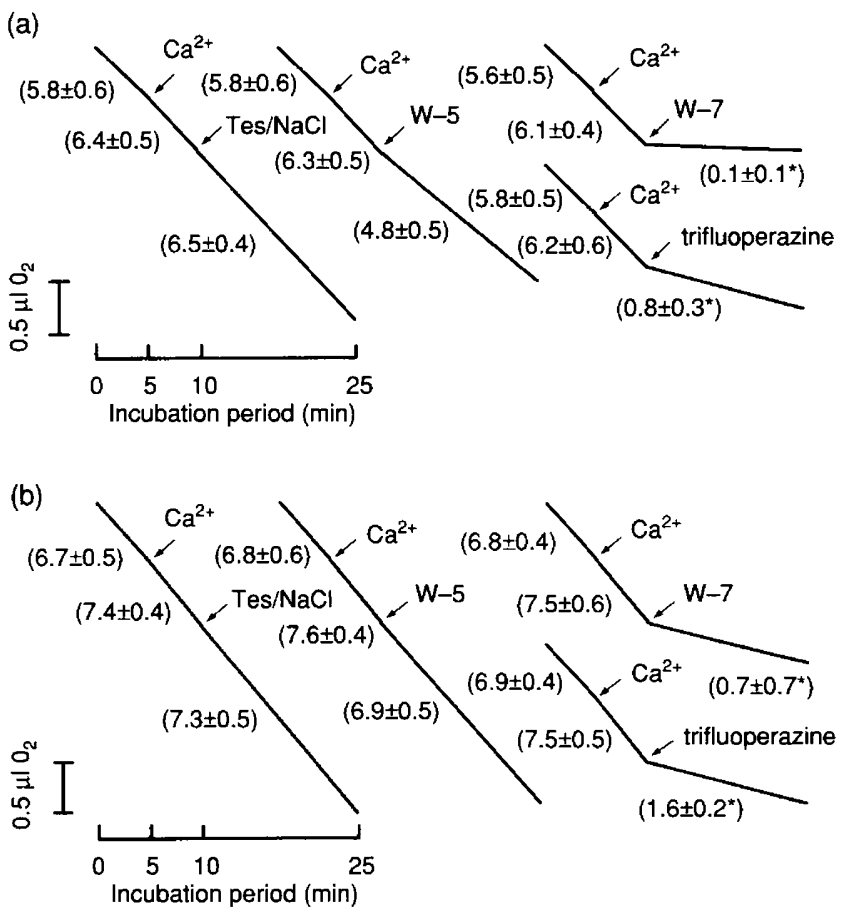

Fig. 8. Oxygen consumption $\left(\mu \mathrm{O}_{2} 10^{-8}\right.$ spermatozoa $\left.\mathrm{h}^{-1}\right)$ of intact fowl spermatozoa after addition of (a) $2 \mathrm{mmol} \mathrm{CaCl}_{2} \mathrm{l}^{-1}, 500 \mu \mathrm{mol}$ $W-7 \mathrm{l}^{-1}, 500 \mu \mathrm{mol} W-5 \mathrm{I}^{-1}$ and $100 \mu \mathrm{mol}$ trifluoperazine $1^{-1}$ at $30^{\circ} \mathrm{C}$, and (b) $2 \mathrm{mmol} \mathrm{CaCl}_{2} \mathrm{l}^{-1}, 100 \mu \mathrm{mol} \mathrm{W}-7 \mathrm{l}^{-1}, 100 \mu \mathrm{mol} \mathrm{W}-5$ $\mathrm{I}^{-\mathrm{I}}$ and $50 \mu \mathrm{mol}$ trifluoperazine $\mathrm{I}^{-1}$ at $40^{\circ} \mathrm{C}$. Each value represents the mean ( \pm SEM) of five samples of spermatozoa. ${ }^{*} P<0.01$ compared with value when calmodulin antagonist was not added (control).

$(P<0.01)$ following the addition of W-7 and trifluoperazine. In contrast, there was no significant decrease after the addition of W-5 or in the control experiment (Fig. 8).

The concentration of ATP in BAPTA/AM-treated spermatozoa decreased slightly at $30^{\circ} \mathrm{C}$ to $38.2 \pm 3.5 \mathrm{nmol} 10^{-9}$ spermatozoa (mean \pm SEM of five samples) compared with those of untreated spermatozoa (control) $(42.6 \pm 4.7)$, but there was no significant difference between them. However, at $40^{\circ} \mathrm{C}$, there was a significant difference $(P<0.01)$ between BAPTA AM-treated spermatozoa and control $(31.7 \pm 2.9$ in BAPTA/AM treatment versus $55.1 \pm 6.0$ in control).

In addition, the concentration of ATP in intact spermatozoa decreased slightly at $30^{\circ} \mathrm{C}$ and $40^{\circ} \mathrm{C}$ after the addition of $\mathrm{CaCl}_{2}$. The subsequent addition of $\mathrm{W}-7$ and trifluoperazine in spite of the presence of $\mathrm{Ca}^{2+}$ caused a significant decrease $(P<0.01)$ in ATP concentration compared with that when no antagonist was added (control) or with W-5 treatment (Fig. 9).

\section{Discussion}

Unlike mammalian spermatozoa, fowl spermatozoa display a reversible temperature-dependent immobilization. This phenomenon might provide a unique model for basic studies on the cellular mechanisms involved in the regulation of flagellar movement. It is particularly useful for studying the stimulatory effect of $\mathrm{Ca}^{2+}$, as at $40^{\circ} \mathrm{C}$ fowl sperm motility is negligible until the addition of millimolar concentrations of

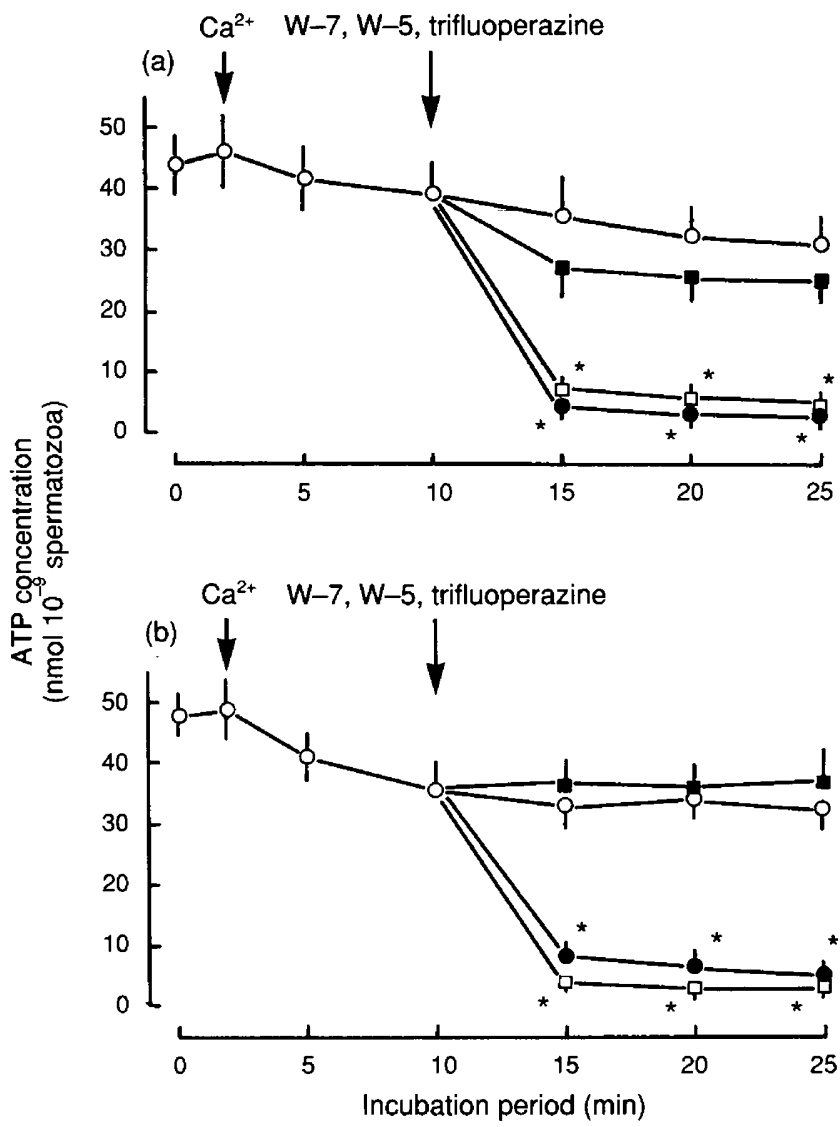

Fig. 9. The concentration of ATP in intact fowl spermatozoa after

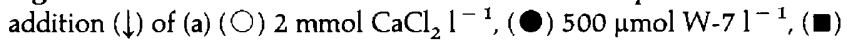
$500 \mu \mathrm{mol} \mathrm{W}-5 \mathrm{l}^{-1}$ and (口) $100 \mu \mathrm{mol}$ trifluoperazine $\mathrm{l}^{-1}$ at $30^{\circ} \mathrm{C}$, and

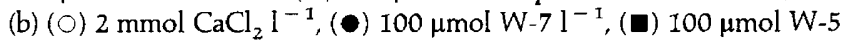
$\mathrm{I}^{-1}$ and $(\square) 50 \mu \mathrm{mol}$ trifluoperazine $1^{-1}$ at $40^{\circ} \mathrm{C}$. Each point represents the mean ( \pm SEM) of five samples of spermatozoa. ${ }^{*} P<0.01$ compared with value when calmodulin antagonist was not added (control) at each incubation period.

$\mathrm{Ca}^{2+}$ to the suspending medium after which 'maximal' motility is achieved (Wishart and Ashizawa, 1987; Ashizawa et al., 1989a; Thomson and Wishart, 1989, 1991). However, detailed mechanisms of this process at the molecular level remain unresolved.

The present study shows that the motility of intact fowl spermatozoa loaded with an intracellular $\mathrm{Ca}^{2+}$ chelator, BAPTA/AM, is negligible at $30^{\circ} \mathrm{C}$, even though spermatozoa are naturally motile at this temperature. However, addition of excess $\mathrm{Ca}^{2+}$ caused the intracellular free $\mathrm{Ca}^{2+}$ concentration to increase from 0 to about $100 \mathrm{nmol} \mathrm{l}^{-1}$ in BAPTAVAMtreated spermatozoa and motility was immediately restored, suggesting that intracellular free $\mathrm{Ca}^{2+}$ is indispensable for the maintenance of fowl sperm flagellar motility.

Calmodulin is a highly conserved, ubiquitous protein involved in mediating the influence of $\mathrm{Ca}^{2+}$ on such cellular processes as signal transduction, cell motility and membrane fusion through its ability to activate key intracellular enzymes (Means et al., 1982). The results reported here suggest that calmodulin regulates fowl sperm motility at a point downstream from $\mathrm{Ca}^{2+}$ fluxes, as the addition of calmodulin 
antagonists such as $\mathrm{W}-7$ and trifluoperazine inhibited the motility of intact spermatozoa at $30^{\circ} \mathrm{C}$ and $40^{\circ} \mathrm{C}$, even in the presence of $\mathrm{Ca}^{2+}$. Furthermore, although the motility of BAPTA/AM-treated spermatozoa could not be restored by the addition of both $\mathrm{W}-7$ and $\mathrm{Ca}^{2+}$, it was instantly restored by the addition of $\mathrm{Ca}^{2+}$ alone. Our results also indicate that most of the calmodulin in fowl spermatozoa may be located in the cytoplasmic matrix, the mitochondria or the membrane, but not retained in the axoneme, since inhibition of motility of intact spermatozoa by the addition of W-7 and trifluoperazine was not observed in demembranated spermatozoa. These results were different from those reported by Brokaw and Nagayama (1985). These authors reported that calmodulin of sea urchin spermatozoa remains tightly bound to the axoneme after extraction with Triton X-100, and that millimolar concentrations of $\mathrm{Ca}^{2+}$ are required to produce 'potentially symmetric' flagella - although some calmodulin is readily solubilized during extraction, and may be either associated with the membrane or simply soluble in the cytoplasmic matrix.

With regard to the action of calmodulin antagonists such as W-7 and trifluoperazine, an alternative explanation should be noted: these antagonists could be interfering, not only with calmodulin, but also with membrane-bound, $\mathrm{Ca}^{2+}$-dependent protein kinase $\mathrm{C}$. The activity of this kinase system is strictly independent of calmodulin and yet is susceptible to nonspecific suppression by calmodulin antagonists (Schatzman et al., 1981, 1983). However, inhibition of both intact and demembranated fowl sperm motility at $30^{\circ} \mathrm{C}$ was not observed by the addition of $\mathrm{H}-7$, the most potent and specific protein kinase $\mathrm{C}$ inhibitor (K. Ashizawa, S. Katayama, T. Kobayashi and Y. Tsuzuki, unpublished). The inhibition of fowl sperm motility by the addition of $\mathrm{W}-7$ and trifluoperazine might therefore be due to the inhibition of $\mathrm{Ca}^{2+}$-calmodulin-regulated enzyme activities.

In these experiments, however, the target and precise mechanisms of the action of calmodulin in the regulation of sperm motility remain to be elucidated. One possibility is that the inhibition of motility is due to energy depletion, since our results have, for the first time, shown that the oxygen consumption and ATP concentrations of fowl spermatozoa decrease markedly after the addition of $\mathrm{W}-7$ and trifluoperazine. It is still unclear whether energy depletion caused by adding W-7 and trifluoperazine is caused by either a calmodulin-regulated or some other, unidentified, process. It has been suggested that calmodulin may be involved in the control of axonemal function by regulating a number of key enzymes, including dynein ATPase, myosin light chain kinase, cyclic nucleotide phosphodiesterases and adenylate cyclase (Tash and Means, 1983). A possible explanation for the influence of calmodulin on sperm motility is that calmodulin in spermatozoa might stimulate the activity of adenylate cyclase responsible for generating cyclic AMP, which is known to be essential for the stimulation of mammalian sperm motility (Gross et al., 1987). However, unlike mammalian spermatozoa, demembranated fowl sperm motility could not be restored by the addition of cyclic AMP at $40^{\circ} \mathrm{C}$ (Ashizawa et al., 1989b, 1992b).

However, attempts to demonstrate a direct association of calmodulin with dynein have yielded conflicting results (Blum et al., 1980; Gitelman and Witman, 1980). The high molar ratios of calmodulin to dynein required to alter dynein ATPase activity (Hisanaga and Pratt, 1984) suggest either that conditions of axoneme or dynein preparation pivotal to preserving such an interaction have not been optimized or that calmodulin regulates motility through an indirect interaction with dynein via another component (Tash, 1989). Evidence for an intermediate calmodulin-regulated component has been obtained by the identification of calmodulin-binding proteins in mammalian spermatozoa (for example, Wasco et al., 1989; Manjunath et al., 1993).

Calmodulin appears to mediate many of the effects of $\mathrm{Ca}^{2+}$ on fowl sperm motility. However, it should be noted that not all effects of $\mathrm{Ca}^{2+}$ on fowl sperm flagellar movement might be mediated by calmodulin, since demembranated sperm motility was inhibited in $\mathrm{Ca}^{2+}$-free medium and was restored by the subsequent addition of $\mathrm{Ca}^{2+}$ alone at $30^{\circ} \mathrm{C}$ (Ashizawa et al., 1992a), even though most of the calmodulin present was probably removed from the axoneme by demembranation.

The authors thank G. J. Wishart, Dundee Institute of Technology, Scotland, UK, for kindly reviewing the manuscript. This study was supported by a grant from the Ministry of Education, Science and Culture, Japan (No. 06660360).

\section{References}

Aitken RJ, Clarkson IS, Hulme MJ and Henderson CJ (1988) Analysis of calmodulin acceptor proteins and the influence of calmodulin antagonists on human spermatozoa Gamete Research 21 93-111

Ashizawa K and Nishiyama H (1978) Effects of temperature on the vigour of motility, oxygen consumption and duration of motility of fowl spermatozoa under aerobic conditions Japanese Poultry Science 15 264-266

Ashizawa K and Okauchi K (1984) Stimulation of sperm motility and oxygen consumption of fowl spermatozoa by a low molecular weight fraction of seminal plasma Journal of Reproduction and Fertility 71 593-598

Ashizawa K and Wishart GJ (1987) Resolution of the sperm motility-stimulating principle of fowl seminal plasma into $\mathrm{Ca}^{2+}$ and an unidentified low molecular weight factor Journal of Reproduction and Fertility 81 495-499

Ashizawa K, Maeda S and Okauchi K (1989a) The mechanisms of reversible immobilization of fowl spermatozoa at body temperature Journal of Reproduction and Fertility 86 271-276

Ashizawa K, Suzuki Y and Okauchi K (1989b) Flagellar movement in demembranated preparations of ejaculated fowl spermatozoa Journal of Reproduction and Fertility $86263-270$

Ashizawa K, Hashiguchi $A$ and Tsuzuki $Y$ (1992a) Intracellular free $\mathrm{Ca}^{2+}$ concentration in fowl spermatozoa and its relationship with motility and respiration in spermatozoa Journal of Reproduction and Fertility 96 395-405

Ashizawa K, Katayama S and Tsuzuki Y (1992b) Regulation of flagellar motility by temperature-dependent phosphorylation of a $43 \mathrm{kDa}$ axonemal protein in fowl spermatozoa Biochemical and Biophysical Research Communications 185 $740-745$

Blum JJ, Hayes A, Jamieson GA, Jr and Vanaman TC (1980) Calmodulin confers calcium sensitivity on ciliary dynein ATPase Journal of Cell Biology 87 386-397

Bogdonoff PD, Jr and Shaffner CS (1954) The effect of $\mathrm{pH}$ on in vitro survival, metabolic activity, and fertilizing capacity of chicken semen Poultry Science $33665-669$

Brokaw CJ (1979) Calcium-induced asymmetrical beating of Tritondemembranated sea urchin sperm flagella Journal of Cell Biology 82 401-411

Brokaw CJ and Nagayama SM (1985) Modulation of the asymmetry of sea urchin sperm flagellar bending by calmodulin Journal of Cell Biology 100 1875-1883

Brokaw CJ, Josslin R and Bobrow L (1974) Calcium ion regulation of flagellar beat symmetry in reactivated sea urchin spermatozoa Biochemical and Biophysical Research Communications 58 795-800 
Brooks JC and Siegel FC (1973) Calcium-binding phosphoprotein: the principal acidic protein of mammalian sperm Biochemical and Biophysical Research Communications 55 710-716

Burgess WH (1983) Characterization of calmodulin and calmodulin isotypes from sea urchin gametes Journal of Biological Chemistry 257 1800-1804

Camatini M, Anelli G and Casale A (1986) Immunocytochemical localization of calmodulin in intact and acrosome-reacted boar sperm European Journal of Cell Biology 41 89-96

Camatini M, Colombo A and Bonfanti P (1991) Identification of spectrin and calmodulin in rabbit spermatogenesis and spermatozoa Molecular Reproduction and Development 28 62-69

Feng B, Bhattacharyya A and Yanagimachi $\mathrm{R}$ (1988) $\mathrm{Ca}^{2+}$ is essential for the motility of plasma membrane-intact, but not of demembranated, hamster spermatozoa Andrologia 20 155-162

Fouquet JP, Fraile B and Kann ML (1991) Sperm actin and calmodulin during fertilization in the hamster: an immune electron microscopic study Anatomical Record 231 316-323

Garbers DL, Hansbrough JR, Radany EW, Hyne RV and Kopf GS (1980) Purification and characterization of calmodulin from sea urchin spermatozoa Journal of Reproduction and Fertility 59 377-381

Gibbons BH and Gibbons IR (1973) The effect of partial extraction of dynein arms on the movement of reactivated sea urchin sperm Journal of Cell Science $13337-357$

Gibbons BH and Gibbons IR (1980) Calcium-induced quiescence in reactivated sea urchin sperm Joumal of Cell Biology 84 13-27

Gitelman SE and Witman GB (1980) Purification of calmodulin from Chlamydomonas: calmodulin occurs in cell bodies and flagella Joumal of Cell Biology $87764-770$

Gross MK, Toscano DG and Toscano WA, Jr (1987) Calmodulin-mediated adenylate cyclase from mammalian sperm Journal of Biological Chemistry $\mathbf{2 6 2}$ 8672-8676

Grynkiewicz G, Poenie M and Tsien RY (1985) A new generation of $\mathrm{Ca}^{2+}$ indicators with greatly improved fluorescence properties Journal of Biological Chemistry $2603440-3450$

Hisanaga S and Pratt MM (1984) Calmodulin interaction with cytoplasmic and flagellar dynein: calcium-dependent binding and stimulation of adenosine triphosphatase activity Biochemistry 23 3032-3037

Hong CY, Chiang BN, We P, Wei YH and Fong JC (1985) Involvement of calcium in the caffeine stimulation of human sperm motility British Journal of Clinical Pharmacology 19 739-743

Jones HP, Bradford MM, McRorie RA and Cormier MJ (1978) High levels of a calcium-dependent modulator protein in spermatozoa and its similarity to brain modulator protein Biochemical and Biophysical Research Communications 82 1264-1272

Jones HP, Lenz RW, Palevitz BA and Cormier MJ (1980) Calmodulin localization in mammalian spermatozoa Proceedings of the National Academy of Sciences USA 77 2772-2776

Kann ML, Feinberg J, Rainteau D, Dadoune JP, Weinman S and Fouquet JP (1991) Localization of calmodulin in perinuclear structures of spermatids and spermatozoa: a comparison of six mammalian species Anatomical Record 230 $481-488$

Katz DF and Overstreet JW (1981) Sperm motility assessment by videomicrography Fertility and Sterility 35 188-193

Kielley WW (1963) Preparation and assay of phosphorylating submitochondrial particles: sonicated mitochondria Methods in Enzymology 6 272-277

Leclerc P, Langlais J, Lambert RD, Sirard MA and Chafouleas JG S(1989) Effect of heparin on the expression of calmodulin-binding proteins in bull spermatozoa Journal of Reproduction and Fertility $\mathbf{8 5} 615-622$

Lindemann CB and Kanous KS (1989) Regulation of mammalian sperm motility Archives of Andrology 23 1-22

Lindemann CB, Goltz JS and Kanous KS (1987) Regulation of activation state and flagellar wave form in epididymal rat sperm: evidence for the involvement of both $\mathrm{Ca}^{2+}$ and cAMP Cell Motility and the Cytoskeleton 8 324-332

Majumder GC, Dey CS, Haldar S and Barua M (1990) Biochemical parameters of initiation and regulation of sperm motility Archives of Andrology 24 287-303

Manjunath P, Chandonnet L, Baillargeon L and Roberts KD (1993) Calmodulinbinding proteins in bovine semen Journal of Reproduction and Fertility $\mathbf{9 7}$ $75-81$
Means AR, Tash JS and Chafouleas JG (1982) Physiological implications of the presence, distribution and regulation of calmodulin in eukaryotic cells Physiological Reviews 62 1-39

Mohri H and Yanagimachi R (1980) Characteristics of motor apparatus in testicular, epididymal and ejaculated spermatozoa. A study using demembranated sperm models Experimental Cell Research 127 191-196

Moore PB and Dedman JR (1984) Calmodulin, a calmodulin acceptor protein, and calcimedins: unique antibody localizations in hamster sperm Journal of Cellular Biochemistry 25 99-107

Munro SS (1938) Fowl sperm immobilization by a temperature-media interaction and its biological significance Quarterly Journal of Experimental Physiology 27 281-287

Nevo AC and Schindler H (1968) Reversible inactivation of cock spermatozoa by temperature Proceedings of the 6th International Congress of Animal Reproduction and Artificial Insemination, Paris Vol II pp. 1637-1640

Schatzman RC, Wise BC and Kuo JF (1981) Phospholipid-sensitive calciumdependent protein kinase: inhibition by anti-psychotic drugs Biochemical and Biophysical Research Communications 98 669-676

Schatzman RC, Raynor RL and Kuo JF (1983) N-(6-aminohexyl)-5-chloro-1naphthalenesulfonamide (W-7), a calmodulin antagonist, also inhibits phospholipid-sensitive calcium-dependent protein kinase Biochimica et Biophysica Acta 755 144-147

Suarez SS, Varosi SM and Dai X (1993) Intracellular calcium increases with hyperactivation in intact, moving hamster sperm and oscillates with the flagellar beat cycle Proceedings of the National Academy of Sciences USA 90 4660-4664

Takeda A (1982) Studies on reversible inactivation of cock spermatozoa by temperature. I. Effects of several factors on reversible inactivation Japanese Poultry Science 19 26-36

Tash JS (1989) Protein phosphorylation: the second messenger signal transducer of flagellar motility Cell Motility and the Cytoskeleton 14 332-339

Tash JS and Means AR (1982) Regulation of protein phosphorylation and motility of sperm by cyclic adenosine monophosphate and calcium Biology of Reproduction 26 745-763

Tash JS and Means AR (1983) Cyclic adenosine 3', 5' monophosphate, calcium and protein phosphorylation in flagellar motility Biology of Reproduction $\mathbf{2 8}$ 75-104

Tash JS, Krinks M, Patel J, Means RL, Klee CB and Means AR (1988) Identification, characterization, and functional correlation of calmodulin-dependent protein phosphatase in sperm Joumal of Cell Biology 106 1625-1633

Thomson MF and Wishart GJ (1989) Elucidation of the mechanism responsible for the temperature-dependent reversible inactivation of the motility of fowl spermatozoa British Poultry Science 30 687-692

Thomson MF and Wishart GJ (1991) Temperature-mediated regulation of calcium flux and motility in fowl spermatozoa Journal of Reproduction and Fertility 93 385-391

Wasco WM, Kincaid RL and Orr GA (1989) Identification and characterization of calmodulin-binding proteins in mammalian sperm flagella Journal of Biological Chemistry 264 5104-5111

Weinman S, Ores-Carton C, Rainteau D and Puszkin S (1986) Immunoelectron microscopic localization of calmodulin and phospholipase $\mathrm{A}_{2}$ in spermatozoa Journal of Histochemistry and Cytochemistry 34 1171-1179

White IG and Voglmayr JK (1986) ATP-induced reactivation of ram testicular, cauda epididymal, and ejaculated spermatozoa extracted with Triton X-100 Biology of Reproduction 34 183-193

Wishart GJ (1982) Maintenance of ATP concentrations in and of fertilizing ability of fowl and turkey spermatozoa in vitro Joumal of Reproduction and Fertility 66 457-462

Wishart GJ and Ashizawa K (1987) Regulation of the motility of fowl spermatozoa by calcium and cAMP Journal of Reproduction and Fertility $\mathbf{8 0}$ 607-611

Wishart GJ and Ross FH (1985) Characterization of a spectrophotometric technique for the estimation of fowl and turkey sperm motility Gamete Research 11 169-178

Yamamoto N (1985) Immunoelectron microscopic localization of calmodulin in guinea pig testis and spermatozoa Acta Histochemica et Cytochemica 18 199-211 